\title{
Behind and beyond Bandung: historical and forward-looking reflections on south-south cooperation
}

\author{
N'Dri Therese Assie-Lumumba
}

\begin{abstract}
In their respective struggles for liberation the Asians and Africans, as oppressed people, joined forces in the first half of the 20th century by forming several pre-Bandung organizations. On the African side people of African descent, from the continent and the Diaspora, united to provide the leadership for substantive participation to the common African-Asian front that led to the Bandung conference of April 18-24 1955. The intelligentsia of African descent, including young students in Western Europe and the United States, played leadership roles in shaping the movements. Among them are W. E. B. Du Bois of the United States and Kwame Nkrumah of Ghana. In terms of the post-Bandung establishment of enduring legacies, it is worth indicating that the resolutions and some of their applications led to global coalitions including the Non-Aligned Movement and G77 within the United Nations. On the occasion of the 50th anniversary that was marked by the April 22-24 2005 Asian-African Summit held in Indonesia African and Asian leaders decided to rekindle the spirit of Bandung and renew their commitment to attain its goal through renewed cooperation between Asia and Africa in adopting the New Asian-African Strategic Partnership (NAASP). Despite the continued challenges that African countries face in varying degrees, a regained confidence building on their assets, especially with different generations of people of the continent and historic and recent Diaspora, with it would be possible to build a global front toward the reaffirmation of global common humanity guided by the spirit of Bandung.
\end{abstract}

\section{Background}

For the African continent and its people, especially Africa South of the Sahara, the Nineteenth Century linked two intertwined historical periods of continent-wide ultimate calamity that redefined the relationship between Africa/ Africans and Europe/Europeans: the transatlantic enslavement from the 1500 to the 1900 and the formal colonization of the African continent following the 1884/ 85 Berlin Conference on the partitioning and colonization of the continent among the European colonial powers (Davidson 1984 and 1991).

Various countries in Asia were subjected to different forms of oppression and domination by European powers through military means. The Africans and Asians had been systematically resisting these oppressive systems over a long period of time before Bandung. However, this

Correspondence: n.assie-lumumba@cornell.edu

Université Félix Houphouët-Boigny, Centre de Recherches Architecturales et Urbaines (CRAU), Abidjan, Côte d'Ivoire, Africa
Conference created a unique momentum in the course of the contemporary world. As Guitard (1969) rightly pointed out, from the ardent supporters to the most powerful detractor, it has been unanimously acknowledged that:

Bandung remains, in colonial history ... a turning point in world history ... [it] was not a miracle ... as it could be and carry the full weight of the future because it was preceded by more obscure meetings, prepared by more modest groupings, that made the first contacts explored their common difficulties ${ }^{\mathrm{a}}$.

Conte (1965) argues that Bandung was in great part the expression of the unacceptable contrast of the arrogant opulence that characterized countries of the West after World War II and the continued degrading life and human misery in the countries of Asia and Africa. The Bandung Conference held in the aftermath of the World 
War II, was marked by the commitment to promote an alternative to the dominant system that created devastation by war and continued the quest to rebuild itself while continuing the exploitation of dominated people. Thus, it was motivated by the idea of forming a global alliance to create and sustain a world of peace and cooperation toward social progress on the global scale.

In their respective struggles for liberation, the Asians and Africans came to the conclusion that with a united front in joining forces, they could break the back of colonial and imperial forces. One important purpose of this article is to analyze some of the pre-Bandung struggles and organizations of people of African descent, from the continent and the Diaspora, which contributed undoubtedly to their readiness and leadership for substantive participation to the common African-Asian front that led to Bandung.

The post-Bandung period led to the establishment of many enduring legacies, and the celebration of many anniversaries. Within the United Nations, for instance, the reflection in this paper focuses on the $50^{\text {th }}$ anniversary that was marked by the April 22-24 2005 Asian-African Summit held in Indonesia. On this occasion, African and Asian leaders decided to rekindle the spirit of Bandung and renew their commitment to attain its goal through renewed cooperation between Asia and Africa in adopting the New Asian-African Strategic Partnership (NAASP). This constitutes the main "beyond Bandung" aspect of the paper.

This paper is a reflective essay using a historical approach to critically examine South-South cooperation as framed in the perspective of African-Asian connection. It is divided into three main sections. The first section analyzes what I have referred to in the paper as "Behind Bandung," with a focus on the early and continuous organizational capacity building in the $20^{\text {th }}$ Century with the deliberate goals of gathering strength for more effectiveness in the struggle. It examines some of the key global and regional factors that contributed, directly or indirectly, to build the momentum toward Bandung. The second section discusses the immediate context of the Bandung Conference, with a focus on some aspects of the specificities of the agency and engagements of African global actors committed to the African-Asian common front. The third section is a forward-looking reflection on post-Bandung in the Twenty-first Century, an analysis of the recent commitment to rekindle the Bandung spirit, and follow through some of the concrete action plans. The conclusion wraps up the reflection while pointing to further research trails to have a fuller appreciation of the history as we move forward.

\section{The African-Asian connection, the global-regional nexus, and factors and actors toward Bandung}

In reiterating the relevance of my historical approach stated in the introduction, it is worth to refer to an African wisdom saying captured in the Akan Sankofa. This proverb articulates the importance of making stops during a journey, to look back to ascertain the appropriateness of the direction and consider the need for a more strategic repositioning to move forward. This idea is also well articulated by John Henrik Clarke, the African-American scholar and activist ${ }^{\mathrm{b}}$ who wrote books such as Clarke (1999), in explaining how crucial history is, when he stated (Clarke 1996):

History is a clock that people use to tell the political and cultural time of the day. It is also a compass that people use to find themselves on the map of human geography. History tells the people where they have been, what they have been, where they are, and what they are. Most important, history tells the people where they still must go and what they still must be.

To articulate the complex process that led the Bandung, it is important to pay due attention to the role of the youth. It may appear as a paradox that many of the pre-Bandung organizations were formed in Europe. The apparent paradox is that the oppressed people were able to organize and articulate their quest for freedom on the lands of the imperial forces. However, the paradox is only apparent. Indeed, these European cities were sites of convergence of people from various colonized societies, most of whom had migrated in pursuit of educational opportunities that the socio-political and economic contexts of their respective countries, most of which were formally colonized, did not offer them. While resident in countries that held colonial and imperial powers, they were able to compare their similar oppressive conditions back home and their quest for positive change. Thus, it was in fact a fertile ground for the Africans and Asians, on their respective sides and together, to meet and organize for change.

In The Souls of Black Folk written in 1903, Du Bois (1969) made one of his most famous observations: "The problem of the twentieth century is the problem of the color-line - the relation of the darker to lighter races of men [sic] in Asia and Africa, in America and the island sea" Du Bois 1969:54). This examination had a meaning not only in the context of the then racially segregated United States, but also globally because colonialism was essentially built on racism. This became significant in the global context and the search for alliance between the African and Asian People. It was framed as an alliance of the Black/Brown and the Yellow (as the Asians were referred to at the time).

The lawyer Henry Sylvester Williams, among other people of African descent from the Caribbean, lived in London at the end of the $19^{\text {th }}$ century and the beginning of the $20^{\text {th }}$ Century. While he was a student, he and other students from West Africa, namely Ghana, the 
Gambia, Nigeria, and Sierra Leone, met and developed relations and came to the realization that African people had a common struggle. In 1900, the year the Ashanti territory was taken by the British, and Queen Yaa Asantewa was sent into exile on the Seychelles Island, the land appropriation in South Africa, etc., moved Williams to lead the organization of a Pan-African conference in London to inform public opinion on the British atrocities in Africa. The message of Marcus Garvey, regarding the Africans in the Diaspora, focused on the return to Africa with dignity. The Pan-Africanists who directly influenced African students and future leaders, and contributed to shape the organization of the struggle for liberation in African countries under European colonial rule were Du Bois and George Padmore.

The Africans and Asians engaged in various movements considered their quest as normal. However, often their organizations and demands were labeled as radical. Guitard (1969): 6 recalls the organization of meetings, on European soil, such as the "Indonesian Days", that were held in France and Belgium, specifically in Bierville and Brussels, respectively. In the first quarter of the $20^{\text {th }}$ Century, the intensification of colonial oppression and exploitation of colonized people in Africa and Asia, paired with the devastating consequences of the First World War caused by the Europeans, engulfed colonized people in the "war efforts" leading to military drafting. This resulted in unprecedented massive destruction. This situation contributed to intensify the organization of oppressed people to free themselves. Various organizations such as the Anti-Imperialist League and the Association of Oppressed Peoples (AOP) are among such early efforts.

Concerning students and other people from the African continent and of African descent living in Europe, it is worth mentioning that the first associations of African students were formed before and especially after World War I. For instance, in North Africa, "Association des Étudiants Musulmans d'Afrique du Nord-Association of Muslim Students of North Africa" was formed in 1912 in Algiers. In 1927, it was transformed into Association des Étudiants Musulmans Nord-Africains (Association of North African Muslim Students with its headquarters in Paris. The same year (1927) the West African Student Association (W.A.S.U.) was formed in London by students from West African British colonies. This association was initially formed to address concerns specific to student life but became more and more openly political, articulating broader societal issues that contributed to explain the conditions of students from colonized countries of Africa.

Between the two World Wars, a few students from the continent and the Caribbean also met in literary circles of Paris, France. While they did not form a specific organization, they discussed themes that had identity and political implications especially "Négritude" (Black identity), given the high politicization of racial identity. This resulted in a decision by Leopold Sédar Senghor of Senegal, Aimé Césaire of Martinique, and Léon Gontran Damas of French Gyana to create a Journal named "l'Etudiant Noir" (The Black Student). But their activities did not develop further on the political front and the Journal was discontinued.

World War II brought an even more sobering realization of the destructive capacity of imperial powers of the West and their lack of any legitimacy to lead the world. This contributed to the intensification of the urge to not only free the oppressed people of Africa and Asia, but to unleash the capacity of Asians and Africans to promote an alternative global leadership for the advancement of peace and development.

It is important to note that among many of these potential and actual change-makers from the colonized world that converged in Europe, young people, especially students, played critical roles. Their courage, daring stance and vision that at the time seemed utopian contributed to paving the way to Bandung (Dieng 2003). Thus in this paper, students of African descent in Europe are presented as key actors in the struggles for freedom and thus, were connected directly or indirectly to the broader movement that led to Bandung.

In the aftermath of World War II, new African social formations emerged and made pressing demand toward independence and definitely immediate reforms. This is the context in which the 1944 Brazzaville Conference was held to address the demand for change in the French colonies, although Africans were not represented. In that frustrating context, the founding of the Syndicat Agricole Africain (SAA-African Agricultural Union), also in 1944, by seven Ivorian plantation owners, with the implicit support of the French Communist Party ${ }^{\mathrm{c}}$ was of particular significance. They were among the first Ivorians to receive a high level of French education. Less than a year after the SAA was created, in early 1945, the number of members had reached 10,000 . This very quickly became a political party formally established as Parti Démocratique de Côte d'Ivoire (Ivorian Democratic Party). The next evolution of SAA was its transformation into an inter-African movement populist party, Rassemblement Démocratique Africain (RDA) that was formally established at a meeting in October 1946, in Bamako (Mali).

African students from French colonies south of the Sahara formed Étudiants RDA (ERDA Students) a youth/student wing of RDA, transcending colonial borders, closer to the Bandung conference. Two wings emerged within ERDA: one wing had a narrower nationalist perspective and focused on the specific 
freedom of the African people. The second wing, which was affiliated to and influenced more directly by the French Communist Party was more radical and universalistic in its message of liberation and freedom.

Despite this internal division, ERDA organized to publish a common journal called $L a$ Voix de l'Afrique Noire (the Voice of Black Africa in which students who later became prominent scientists (e.g. Cheikh Anta Diop) published articles that had considerable impact on the Pan-Africanist consciousness of the African students and commitment for African unity and participation in the global struggle for liberation (e.g. "Vers Une Idéologie de l'Afrique Noire"-Towards an Ideology of Black Africa, "la Lutte en Afrique Noire"-The Struggle in Black Africa).

Students felt that ERDA was not able to meet the need for all students to participate directly and more actively in the struggle for liberation in Africa. Moreover they wanted students from French West Africa, French Equatorial Africa, Cameroun and Togo to belong to the same association. To create this association two constituent Congresses were held in 1950. The first one took place in Lyon in April 1950 and the second one in Bordeaux in December 1950. The students created the Fédération des Étudiants d'Afrique Noire en FranceFEANF (Federation of Students from Black Africa in France headquartered at FEANF in Paris (UNESCO 1994; Dieng 2003).

FEANF was, from its inception, for total independence. Présence Africaine published a document in 1952, entitled "Les Étudiants Noirs Parlent" (Black Students Speak Out). The committee of patrons included André Gide, Albert Camus, Paul Hazoumé, Jean-Paul Sartre and Richard Wright among other public intellectuals and influential literary and political figures. In terms of some of its achievements, as Sékou Traoré (a mathematician from Guinée-Conakry) explained, no matter what overall judgment may be cast on FEANF, it distinguished itself historically by unequivocally pronouncing the nonnegotiable and unconditional essence of independence of African countries, which was at the time considered utopian (Traoré 1973).

The motto of FEANF was "integration to the masses" anywhere. For FEANF independence and African Unity were inseparable. Their arguments were that one could not claim to fight for independence within the boundaries created to meet the interests of the European colonial powers. Therefore, their arguments and visions were consistent with the four goals and ten principles that were articulated and adopted at the Bandung Conference (Kadir 1958).

Furthermore, to use the notion articulated by a worldrenowned scholar, public intellectual and activist (Amin 1990), who attended the Bandung Conference, in his 1990 book Delinking: Towards a Polycentric World, considered an important part of the struggle of colonized people in breaking the colonial ties and to freely create new alliances of choice toward a world without domination and exploitation, a world of peace and equal opportunity for development and social progress.

The aforementioned African students' movements and organizations contributed to expose common deplorable conditions and the non-negotiable quest for global justice that Asian people in general had been articulating, as they too suffered the consequences of conquest and domination mostly by the same Western countries that oppressed the people of Africa, including those who were forced into the Diaspora through the Transatlantic enslavement.

This is why when analyzing the African-Asian search for freedom, from the African side, the framing must be more systematically encompassing by referring to the Global Africa, which includes people from the African continent and those from historic African Diaspora that grew out of centuries of transatlantic enslavement. Indeed, the forces and actors in the two spaces on the tow sides of the Atlantic Ocean are irreversibly intertwined. Thus, drawing in part from an earlier paper (Assie-Lumumba 2010), here I focus on the lived experiences of two contemporary giants of global Africa who played central roles in the effort to establish a functional connection and common front between Africa and Asia. They are the late President/Dr. Kwame Nkrumah and Professor/Dr. W. E. B Du Bois, who embody Pan Africanism as a Foundation for the Asian African Connection.

\section{Global African voices in the Bandung and Asian-African connection in search of alternative for global development} Considering their individual and converging political trajectories in assessing contradictions on the world scale and possibilities for global coalition, W. E. B. Du Bois and Kwame Nkrumah embraced both PanAfricanism and the search African and Asian constructive solidarity. Thus, their engagements are used to illustrate the African side of Asian-African Connection in Search of Alternative for Global Development and the role of two of the most prominent figures of African decent.

Padmore (1971) pointed out that although Du Bois gave a special meaning to Pan-Africanism, many others did express the need for Pan Africanist perspective in the struggles of African people. There are various dimensions of Pan-Africanism including the one that emphasized the continent and constituted the ground of joint voices and alliances between leaders such as Kwame Nkrumah of Ghana and Gamal Abdel Nasser of Egypt. In this paper I focus on the dimension that includes the continent and the Diaspora that resulted from the transatlantic enslavement. 
Du Bois gave a specific impetus to Pan-Africanist consciousness, particularly through a series of Pan-African congresses, most of which were held in Europe. Following the aforementioned Pan-African conference, five Pan-African congresses were organized and held in the West, before Bandung: the first one was held in Paris in 1919, the second in 1921 in London, the third in 1923 in London, the fourth in 1927 in New York, and the fifth in 1945 in Manchester.

Thus, in the beginning of the $20^{\text {th }}$ Century, the early years of organized efforts toward Afro-Asian collaboration coincided with the same period when the lives and histories of the two giants W. E. B. Du Bois and Kwame Nkrumah started to converge. This convergence started from the United States to Europe and back to the African continent while they intensified their respective and collective struggle for freedom, justice and peace as a pre-requisite for social progress for the Africans and oppressed people everywhere.

Du Bois and Nkrumah met in the United States where Nkrumah spent ten years, from 1935 to 1945, primarily as a student starting his education at Lincoln University in Pennsylvania. He was recommended by his mentor, Nnamdi Azikiwe upon his return to Africa from the United States where he also studied at Lincoln University. Azikiwe later became the first President of Nigeria at Independence in 1960.

The time Nkrumah spent in the United States included part of the period between the two World Wars and the entire duration of WWII, an essentially European war for which, like Asians from various countries under European colonial rule, Africans, African Americans, and the people of African descent elsewhere fought for liberty and freedom that they were not allowed to enjoy in their respective territories. In spite of the continued resistance and various means to fight colonial domination, Africa was still firmly under colonial rule and the United States was still governed by Jim Crow laws, awhile the islands in the West Indies were still controlled by European old slave and colonial powers.

This period also coincided with the organization of the $5^{\text {th }} 1945$ Pan African Congress, which took place in Manchester (United Kingdom) and in which both $\mathrm{Du}$ Bois and Nkrumah played the prominent roles as President and Secretary, respectively. Given their respective ideologies and the actual power of the dominant system, they both strongly expressed the need for a global partnership that would provide an alternative to the alliance of Western Europe and its extension in the Americas. Indeed, both $\mathrm{Du}$ Bois and Nkrumah were seeking an alliance that could tilt the global system toward mutual respect, an appreciation of, and commitment for, justice and peace as sine qua none for social progress.

The most decisive articulation of the need for a united African-Asian front for liberation and equality worldwide is located between the two World Wars. In 1924 a group of Africans and Asians in Europe formulated the AntiImperialist League. This organization was transformed into the Association of Oppressed Peoples (AOP). The AOP meeting held in Brussels in February 1927 was attended by 175 delegates from 37 countries and territories of the time. Considering its goal and the composition of the participants, it has been referred to as the precursor of "Afro-Asian solidarity, the forerunner of the conference at Bandung". It is indeed significant that the participants included Nehru of India, Ho Chi Minh of Vietnam, Muhammad Hatta of Indonesia, Madame Sun Yat-sen of China, and Léopold Sedar Senghor of Senegal. As Conte (1965) 21 recalls, this meeting referred to as the "first Bandung" was attended by other eminent personalities such as "Barbusse ... Einstein, Lansburry". Win (2010): 43 explained that on Asian soil, there was another forerunner of Bandung as stated in the title of his article "The 1953 Asian Socialist Conference in Rangoon: precursor to the Bandung conference".

In the United States, debates, between the two World Wars focused on two major dualist articulations: Orientalism and Eurocentric race theory, on the one hand, and Bolshevism and anticommunism on the other. In these polar representations of the world, actual and potential forces were driven by conflicts, some of which led to full-fledged wars with destructive consequences of which World War II provided a sadly eloquent illustration that made the quest for global peace and development even more urgent. In this context, the Bandung Conference from the $18^{\text {th }}$ to the $24^{\text {th }}$ of April 1955 (Kahin 1956), was appropriately characterized as a natural and timely evolution (Abdulgani 1981).

In April 1954, the Indonesian Government made an initial proposal for the organization of an Asian-African conference. In December of the same year, the Prime Ministers of five Asian countries "Burma (now Myanmar), Ceylon (now Sri Lanka), India, Indonesia and Pakistan" held a Conference in Bogor (Indonesia). At that meeting they reached an agreement to serve as co-conveners of an Asian-African conference. The consensus was to jointly call the conference that the five countries had proposed, after which the historic African-Asian meeting was held.

One of the world's most prominent intellectuals and political figures of all time, W. E. B. Du Bois, was unable to attend the Bandung Conference although he wanted to. In the aftermath of the destruction of WW II, with the particular significance of the use of the atomic bomb on Hiroshima and Nagasaki, many people including prominent individuals organized to promote a pacifist message. This is the context in which the organizations that scientists such as Albert Einstein advocated for and were later created ${ }^{\mathrm{d}}$.

As one of the numerous undertakings that $\mathrm{Du}$ Bois either initiated or significantly contributed to, in April 
1950, he established and was elected the chairperson of the Peace Information Center that was set up for the purpose of collecting and disseminating information on the international peace movement. One of the specific objectives of the Center was to prevent any future use of atomic weapons by any nation in the world. The goal and targeted beneficiaries of the work that Du Bois was engaged in transcended ideological differences, ignored national borders, and crossed color lines as he was committed to humanity. His passion then, as before and later in his life journey was to work toward a world of justice and peace. However, in the context of the Cold War and especially the McCarty era, less than a year after the creation of the Peace Information Center, in February 1951, $\mathrm{Du}$ Bois was indicted under the Foreign Agents Registration Act that was adopted shortly before WWII, in 1938. He was tried as "an agent of a foreign principal". Although he was later acquitted, he was prevented from attending the Bandung Conference as the government of the United States confiscated his passport.

Nevertheless, he managed to have two powerful messages delivered: 1) a message of solidarity or "the Greetings" to the conference organizers and participants, and 2) a statement on "The Declaration of Independence" of African countries. Both messages were read to the conference and "were met with warm applause by the delegates" Du Bois (1982):236. In his Greetings he stated:

We wish you well and bid you stand staunch and fast for peace and freedom, for an Africa and Asia equal with and independent of Europe and America, standing on its own feet, governing themselves as they decide, ... and establishing and conducting their own industrial systems as they see fit and not as British or American command Du Bois (1982):236.

In his Declaration of Independence of Africa, he wrote:

The people of Africa, black and white, brown and yellow, have the right to freedom and self-government, to food and shelter, education and health. ... Africa is for the Africans; its land and labor; its natural wealth and resources; its mountains, lakes and rivers; its cultures and its soul. ... Let the white world keep its missionaries at home to teach the Golden Rule to its corporate thieves. ... Peace on earth; no more war. ... All Hail Africa (Du Bois 1982: 236-237).

Nkrumah did not attend the Bandung Conference either (Who's Who 1955). As Ghana was still a British colony of Gold Coast for 23 more months, he could not travel as head of state. However, the Gold Coast was represented by a three-member representation with Kojo
Botsio (Minister of State and member of Legislative Assembly) as head of delegation (Kementerian Penerangan Republik Indonesia 1955) Miguel Francis Dei-Anang and James Gilbert Markham. Despite its relatively small size, the delegation of the Gold Coast, which stood with considerable pride just two years before the independence of the country, made a substantive contribution and lasting impact as indicated in the annals of history. Indeed, in terms of the clarity and strength of the political position, Ghana/Gold Coast was a key and powerful representative of Africa.

It is important to mention the other African countries that were represented at the Bandung Conference: Egypt, with the powerful voice of Nasser, Liberia, Ethiopia, Libya, and Sudan.

The final joint Communique of the Conference articulated four main goals needed for cooperation in areas of such critical importance such as the economy, culture, promotion of world peace and the urgency of addressing issues related to "dependent peoples", human rights and the actualization of the United Nations enshrined rights of people to self-determination (Bandung Committee 1955). More specifically, four main goals were articulated in the areas of combating "fear" and building "trust", "confidence", "goodwill" towards each other," and by practicing "tolerance" and living "together in peace with one another as good neighbours" and developing "friendly cooperation" (Kadir: 4). Based on these goals ten fundamental principles were adopted (Kadir: 4-5):

1. Respect for fundamental human rights and for the purposes and principles of the Charter of the United Nations.

2. Respect for the sovereignty and territorial integrity of all nations.

3. Recognition of the equality of all races and of the equality of all nations large and small.

4. Abstention from intervention or interference in the internal affairs of another country.

5. Respect for the right of each nation to defend itself singly or collectively, in conformity with the Charter of the United Nations.

6. (a) Abstention from the use of arrangements of collective defense to serve the particular interests of any of the big powers.

(b) Abstention by any country from exerting pressures on other countries.

7. Refraining from acts or threats of aggression or the use of force against the territorial integrity or political independence of any country.

8. Settlement of all international disputes by peaceful means, such as negotiation, conciliation, arbitration 
or judicial settlement as well as other peaceful means of the parties' own choice, in conformity with the Charter of the United Nations.

9. Promotion of mutual interests and co-operation. 10. Respect for justice and international obligations.

This Bandung Conference captured the areas of critical importance in the search for justice, equality in human dignity and rights in every sphere of society and aspiration for social progress that had been hitherto and continued to be the ground for the struggle for independence and an end to Apartheid in Africa.

$\mathrm{Du}$ Bois embodied what has been referred to in the annals of history as "the Bandung Spirit". He was a pilgrim of peace and social progress who travelled extensively across the globe. Deliberately, but also pushed by the politics of the Cold War and the persistently racialized politics of increasingly conservative domination of the United States with far-reaching implications for the world, he became more and more a leftist radical. He intensified his travels to Asia with a purpose, focusing on China where he observed the achievements and great potentials, at home and globally and possibilities in cooperation with Africa. He argued that given the global system of skewed power distribution along racial lines, the oppressed people must unite. He stated with great passion and hope: "Come to China, Africa, and look around" (1968:407).

Du Bois was still traveling to Asia in his 90s. As he recalled: "When in Peking, my $91^{\text {st }}$ birthday was given national celebration. I pled for unity of China and Africa ..." He went on to articulate some of the highlights of the day by adding that on this occasion, he was offered the opportunity "to speak to the people of China and Africa and through them to world. Hail, then, and farewell, dwelling places of yellow and black races. Hail human kind" (Du Bois 1968:405).

\section{Post-colonial context, global dynamics and the call for the renewal toward a model for world-wide social progress and peace}

At a time when Nkrumah was discussing the Congo crisis, and the disposition of the East-west relations which were perceived as doomed and leading inevitably toward armed conflict, (Nkrumah 1961), in his book entitled $I$ Speak Freedom (pp. 280-281) stated: "The Afro-Asian nations, if they act together, might prove strong enough to be a decisive force for peace in the world".

In the logic of the dependency arguments, national resources were articulated as "zero sum commodities". Generally, the Western imperial and former colonial powers have never supported decolonization and true self-determination of the African people. This argument was documented by Rodney (1972) in his seminal book entitled: How Europe Underdeveloped Africa. Even a Conservative British Prime Minister, Harold Macmillan, observed and stated in early 1960 in Ghana and South Africa that "there was a wind of change" over the continent that no one could stop. Therefore, what was termed later as neo-colonial policies was firming up even with the quest for freedom and self-determination as captured in Bandung.

Ampiah (2007) summed up the reaction of the key Western powers toward the Bandung Conference, specifically the United States as ranging "from revulsion to 'Benevolent indifference', and reluctant acceptance”. The process of formal decolonization continued with the backing of the resolve that emerged from Bandung. At the time of the Conference only Ethiopia, Liberia and Egypt had the national autonomy, and provided further impetus with a global base in the struggle toward decolonization. In 2014, only Western Sahara aka Sahrawi Arab Democratic Republic remains a contentious case. There is no doubt that the common front and support from outside the African continent played a role in advancing self-determination.

Arguably, the founding of the Non-aligned Movement with its preparatory meeting and constitutive Summit on September 1, 1961 in Belgrade, was one of, if not the highest actualization of the ideas in goals and principles that were adopted at the Conference (Mišković et al. 2014). The Group of developing countries that was formally established during the United Nations Conference on Trade and Development in June 1964 was a framework to give a meaning to the economic cooperation and social progress envisioned in the Bandung broad goals and principles.

Under Nkrumah, Ghana remained active in the AfroAsian group at the United Nations. By a terrible irony, three years after Du Bois' passing, Nkrumah was on his way to China when he lost power to the first Ghanaian military coup d'état that took place on February $24^{\text {th }}$ 1966. During the journey and when he landed in Beijing, he was unaware of the coup. As a basic courtesy and sign of respect for his dignity, he was received on his arrival with full honors before the Chinese authorities brought the news to him. That was perhaps a sign of the changes to come in African and Asian countries internally, regionally and on the global scale, and the promise of an alternative global alliance for peace and justice. African countries experienced major setbacks, in great part reflecting the impact of global Cold War politics (Nkrumah 1971).

With the end of Apartheid in South Africa, there was a renewed energy on the African continent. Thus, South Africa took the lead in the adoption of the New AsianAfrican Strategic Partnership (NAASP) which was conceived as a step towards rekindling the spirit of 
Asian-African Solidarity and Cooperation. Thus Indonesia made a point to successfully host the 50th commemoration of the Asian-African Summit on April 22-24 in both Jakarta and Bandung, and specifically in conjunction with the Commemoration of the Golden Jubilee of the AsianAfrican Conference of 1955 (Wirajuda et al. 2005).

There was an effort to revive the spirit of Bandung as it was captured in the Final Communique of the 1955 Conference. New resolutions and plans for future cooperation between Africa and Asia were enthusiastically adopted. Subsequently, the New Asian African Strategic Planning (NAASP) was created to specifically renew the spirit of Bandung founded on solidarity, friendship, and cooperation to effectively and practically move forward in tackling issues of critical concern. The resolve to revive the spirit of solidarity and cooperation was enshrined in a common document that came out of the 2005 Summit in Jakarta on April 22-23 that was officially launched in Bandung on April 24. This is where the New AsianAfrican Strategic Planning (NAASP) was co-signed by the two Summit co-hosts, President Susilo Bambang Yudhoyono of Indonesia and President Thabo Mbeki of South Africa and full participation of the United Nations, whose Secretary-General was the Ghanaian Kofi Annan (Wirajuda et al. 2005). It stipulated: "We, the Leaders of Asian and African countries, have gathered in Jakarta, Indonesia on 22-23 April 2005 for the Asian-African Summit to reinvigorate the Spirit of Bandung as enshrined in the Final Communique of the 1955 Asian-African Conference and to chart the future cooperation between our two continents towards a New Asian-African Strategic Partnership (NAASP)". There have been various meetings since 2005, most of which are held in Indonesia (Jakarta, Bandung, Bali). They deal with various dimensions of economic and technological cooperation. NAASP has also included a specific component on "Capacity Building for Palestine".

There were obvious differences between 1955 and 2005. For one, the 1955 Bandung Conference had 29 participating countries (37 countries and territories) and their respective delegates while the 2005 Summit had 106 participating countries, representing more than half of the countries in the world. Also, efforts are still being made through the New Global Forum, which has held its meetings, and have met in different developing countries encompassing countries outside Africa and Asia and, like the Non-Aligned Movement and G77, has reached beyond Africa and Asia (Arnold 2006).

Since the 2005 Summit, there have been various areas of African-Asian collaboration on bi-lateral or multilateral bases. They include much focused areas such cooperation to fight trans-national organized crime, food Security, Energy Security, higher education collaboration and programs for achieving gender equality and empowerment of women. Some of these programs are organized in collaboration with UN agencies such as UNEP (United Nations Environment Programme) workshop. The fundamental questions of a comprehensive revisiting of Bandung is much needed to pursue in a coherent and consistent manner the "Reviving the spirit of Asian-African Solidarity and Cooperation" to consolidate an alliance toward global peace end social progress.

The global, regional and national socio-political contexts of Bandung have evolved. However, as far as the recognition of Africa as a world region is concerned, many of the socio-economic factors that were articulated in calling for the Conference continue to prevail albeit with different manifestations. A renewed committed toward the a world of genuine peace, including elimination of proxy war, would be needed so that even the aforementioned more focused programs of by- and multilateral cooperation between African and Asian countries can be guided by the Bandung spirit and quest for providing a model of international cooperation guided by a moral compass.

A more rigorous assessment of the achievements, especially with NAASP and the forthcoming $60^{\text {th }}$ anniversary would require a separate paper with an in-depth description with quantitative and qualitative data and critical analysis with is beyond the scope and space allocated to this paper.

\section{Conclusion}

This era is a crucial period in the status of the African continent as many of its countries are celebrating the $50^{\text {th }}$ Anniversary of independence. Ghana had the most outstanding celebrations in 2007. These celebrations are expected to continue for several more decades, even toward the middle of the Twenty first Century. Without undermining the importance and significance of these celebrations, there remains many issues that require concerted efforts for the continent and its peoples to achieve social progress, and a feeling of well-being among the African people globally. Beyond this, the continent also needs trustworthy allies in the global context.

Questions regarding the actual progress have been asked. Had the Afro-Asian group been successful in offering an alternative model shaped by peace and development possibilities, what would the world be like today? What would the state of African countries and people be? Although we will never have answers to these questions, the conceptualization of the New AsianAfrican Strategic Partnership (NAASP) aimed at reviving the spirit of African-Asian solidarity and cooperation is being articulated in a fundamentally crucial era.

The year 1963 was also a turning point of missed opportunity in shaping Africa's fate and future, at the 
creation of OAU (Organization of African Unity). The progressive and Pan-African positions that reflected the Bandung four goals and ten principles were promoted by the Casablanca group in which (Nkrumah 1970) played a prominent role was defeated by the Monrovia group that opted for a more conservative position that facilitated the continued neo-colonial framework for the relationships between African countries within the colonially inherited artificial borders and between Africa and the West and the rest of the world.

This turning point has had far-reaching and entrenched legacies on why half a century after the process of independence started, African countries are still struggling amidst old and new development challenges, while their Asian counterparts have evolved into regional or world authorities. The lack of progress in the African continent has impaired the actual bargaining power that African countries have and can create in establishing their relationship of cooperation with Asian countries of various sizes and power from the emerging economies to the giant China that participated in Bandung Conference. African countries require a renewed and clear vision, as well as political will, to guide them in rekindling a version of African-Asian alliance in a relatively strong position with bargaining power toward social progress. If the spirit of Bandung prevails African countries could have another chance.

Despite the continued challenges that African countries face in varying degrees, a regained confidence building on her assets, especially with different generations of people of the continent and historic and recent Diaspora, it would be possible to build a global front toward the reaffirmation of global common humanity guided by the spirit of Bandung. This is an area where the youth may also play critical roles in reframing the search and utilizing the resources of the $21^{\text {st }}$ century to organize for the creation of a new global community that is guided by the genuine realization of shared humanity. The new journal devoted to Bandung is a constructive role in providing a forum for critical examination and application of a permanent corrective policy instrument for collective well-being.

\section{Endnotes}

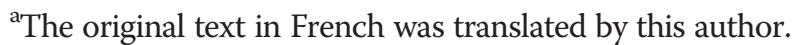

${ }^{\mathrm{b}} \mathrm{A}$ contemporary and friend of Kwame Nkrumah who was engaged in struggle for freedom of oppressed people.

${ }^{\mathrm{c}}$ While the French Communist Party was participating in the government in France a communist governor, Latrille, was sent to Côte d'Ivoire. Taking advantage of the governor's sympathetic disposition and some of reforms recommended at the Brazzaville Conference, the seven Ivorian plantation owners founded the Syndicat Agricole Africain.
${ }^{\mathrm{d}}$ The current World Academy of Art and Science formally established after Einstein passed away always recognized the seminal role he played that led to its founding. This author has been honored to become a life-time member since 2006.

Received: 20 November 2014 Accepted: 20 November 2014 Published online: 25 July 2015

\section{References}

Abdulgani, Roeslan. 1981. The Bandung connection: the Asia-Africa conference in Bandung in 1955/Roeslan Abdulgani; translated by Molly Bondan. Singapore: Gunung Agung.

Amin, Samir. 1990. Delinking: towards a polycentric world. Wolfers, London, Atlantic Highlands, N.J.: Zed Books.

Ampiah, Kweku. 2007. The political and moral imperatives of the Bandung conference of 1955: the reactions of the US, UK and Japan. Folkestone, UK: Global Oriental.

Arnold, Guy. 2006. Historical dictionary of the non-aligned movement and third world. Lanham, Md: Scarecrow Press, Inc.

Assie-Lumumba, N'Dri. 2010. "Africa-Asia Connection in the Global Context: The Pursuit of Solidarity for Peace and Social Progress" CODESRIA Bulletin, Nos 3 \& 4, pp. 25-29

Bandung Committee. 1955. Asian-African conference. Bandung, Indonesia, speeches and communiqués. Djakarta: Kementerian Penerangan Republik Indonesia.

Clarke, John Henrik. 1996. A great and mighty walk, [videorecording] [S.I.]. New York: B. lack Dot Media.

Clarke, John Henrik. 1999. My life in search of Africa. Chicago: Third World Press. Conte, Arthur. 1965. Bandoung: Tournant de l'Histoire, 18 avril 1955. Paris: R. Laffont.

Davidson, Basil. 1991. African civilization revisited: from antiquity to modern times. Trenton, NJ: Africa World Press.

Davidson, Basil. 1984. Episode 1, "different but equal" [videorecording]/a Mitchell Beazley television, RM arts/channel four Co-production in association with the Nigerian television authority; written and presented by Basil Davidson; directed by John Percival. Africa: Passion and memory: Blacks in Hollywood films.

Dieng, Amady Aly. 2003. Les Premiers Pas de la Fédération des Étudiants d'Afrique Noire en France (FEANF), 1950-1955: de I'Union Française à Bandoung. Paris: I'Harmattan.

Du Bois, W. E. B. (William Edward Burghardt). 1968. The autobiography of W. E. B. Du Bois; a soliloquy on viewing my life from the last decade of its first century. New York: International Publishers.

Du Bois, W. E. B. (William Edward Burghardt). 1969. The souls of black folk. With introductions by Nathan Hare and Alvin F. Poussaint. New York: New American Library.

Du Bois, W. E. B. (William Edward Burghardt). 1982. Writings by W.E.B. Du Bois in periodicals edited by others/collated and edited by Herbert Aptheker, vol. 4. Millwood, NY: Kraus-Thomson Organization Limited.

Guitard, Odette. 1969. Bandoung et te Réveil des Peuples Colonisés, 3rd ed. Presses Universitaires de France: Presses Universitaires de France.

Kadir, RHAbdul. 1958. The Bandung way: the most important development of the present century. New Delhi: The Unity Book Club of India.

Kahin, George McTurnan. 1956. The Asian-African conference, Bandung, Indonesia, April 1955. Ithaca, NY: Cornell University Press.

Mišković, Nataša, Harald Fischer-Tiné, and Nada Boškovska (eds.). 2014. The non-aligned movement and the cold war: Delhi-Bandung-belgrade. New York, NY: Abingdon, Oxon

Nkrumah, Kwame. 1961. I speak of freedom: a statement of African ideology. London: Heinemann.

Nkrumah, Kwame. 1970. Africa must unite. New York: International Publishers.

Nkrumah, Kwame. 1971. Ghana; the autobiography of Kwame Nkrumah. New York: International Publishers.

Padmore, George. 1971. Pan-africanism or communism, foreword by Richard Wright; introduction by Azinna Nwafor. Garden City, NY: Doubleday.

Rodney, Walter. 1971. How Europe underdeveloped Africa. London: BogleL'Ouverture Publications.

Traoré, Sékou. 1973. Responsabilités Historiques des Étudiants Africains. Paris: Éditions Anthropos.

UNESCO. 1994. African student movements in the political and social evolution of Africa from 1900 to 1975. Paris: UNESCO. 
Who's Who. 1955. Asian-African conference. Djakarta: Joint Secretariat, Asian-African Conference.

Win, Kyaw Zaw. 2010. The 1953 Asian socialist conference in Rangoon: precursor to the Bandung conference. In Bandung 1955: little histories, ed. A Finnane and D McDouglas. Caulfield: Monash University Press.

Wirajuda, NHassan, Juwono Sudarsono, Roeslan Abdulgani, Jamie Mackie, Dino Patti Djalal. 2005. Asia, Africa; Africa, Asia: Bandung, towards the first century/ foreword by Susilo Bambang Yudhoyono; with messages from Thabo Mbeki, Kofi Annan Jakarta. Republic of Indonesia: Indonesia Dept. of Foreign Affairs.

Submit your manuscript to a SpringerOpen ${ }^{\odot}$ journal and benefit from:

- Convenient online submission

- Rigorous peer review

- Immediate publication on acceptance

- Open access: articles freely available online

- High visibility within the field

- Retaining the copyright to your article

Submit your next manuscript at $>$ springeropen.com 